\title{
Treatment of high-strength wastewater in tropical constructed wetlands planted with Sesbania sesban: Horizontal subsurface flow versus vertical downflow
}

\author{
Truong Hoang Dan ${ }^{\mathrm{a}, *}$, Le Nhat Quang ${ }^{\mathrm{b}}$, Nguyen Huu Chiem ${ }^{\mathrm{c}}$, Hans Brix ${ }^{\mathrm{d}}$ \\ a Department of Environmental Management and Natural Resources, College of Environment Er Natural Resources, Cantho University, Cantho City, Viet Nam \\ ${ }^{\mathrm{b}}$ Department of Environmental Management and Natural Resources, College of Environment E Natural Resources, Kien Giang University, Cantho City, Viet Nam \\ ${ }^{c}$ Department of Environmental Science, College of Environment \& Natural Resources, Cantho University, Cantho City, Viet Nam \\ d Department of Biological Sciences, Aarhus University, Ole Worms Allé 1, DK-8000 Århus C., Denmark
}

\section{A R T I C L E I N F O}

\section{Article history:}

Received 19 May 2010

Received in revised form 23 July 2010

Accepted 25 July 2010

Available online 30 August 2010

\section{Keywords:}

BOD

COD

Food processing waste water

Nitrogen

Removal rate constant

Phosphorus

Plant uptake

\begin{abstract}
A B S T R A C T
Treatment of various types of wastewaters is an urgent problem in densely populated areas of many tropical countries. We studied the potential of using Sesbania sesban, an $\mathrm{N}_{2}$-fixing shrub, in constructed wetland systems for the treatment of high-strength wastewater. A replicated horizontal subsurface flow system and a saturated vertical downflow system was established with planted and unplanted beds to assess the effects of system design and presence of plants on treatment performance. The systems were loaded with a mixture of domestic and pig farm wastewater at three hydraulic loading rates of 80 , 160 and $320 \mathrm{~mm} \mathrm{~d}^{-1}$. The $S$. sesban plants grew very well in the constructed wetland systems and produced $17.2-20.2 \mathrm{~kg}$ dry matter $\mathrm{m}^{-2}$ year $^{-1}$ with a high nitrogen content. Mass removal rates and removal rate constants increased with loading rate, but at $320 \mathrm{~mm} \mathrm{~d}^{-1}$ the effluent quality was unacceptable and hydraulic problems appeared. Mass removal rates and removal rate constants were much higher than reported in other studies probably because of the high-strength wastewater, the high loading rates and the tropical conditions. Planted systems removed pollutants much more efficiently than the unplanted controls. Direct plant uptake constituted only up to $8 \%$ of the total-N removal and $2 \%$ of the P removal at the lowest loading rate, and was quantitatively of low importance compared to other removal processes. The significant effects of plants were therefore related more to their indirect effects on the removal processes. This study for the first time documents that $S$. sesban can be used in constructed wetland systems for the treatment of polluted water while at the same time producing a valuable $\mathrm{N}$ rich biomass that can be used for animal fodder or soil amendment.
\end{abstract}

(C) 2010 Elsevier B.V. All rights reserved.

\section{Introduction}

The rate of global population growth, urbanization, economic and industrial development, causes many challenges and pressures due to the impacts of wastewater discharges on surface water quality. To achieve water quality for safe agricultural production and public health, water treatment should be solved with reasonable and economic solutions. The use of wetlands in water pollution control is a cost-effective treatment option that is widely used around the world (Vymazal et al., 2006; Kadlec and Wallace, 2009). Constructed wetland systems are engineered systems that have been designed and constructed to utilize natural processes involving wetland vegetation, soils, and associated microbial assemblages to assist in treating wastewater. They are designed to take advantage of many processes that occur in natural wetlands (Kivaisi,

\footnotetext{
* Corresponding author. Tel.: +84 71 831954; fax: +84 71830247

E-mail address: thdan@ctu.edu.vn (T.H. Dan).
}

2001; Mitsch and Gosselink, 2007). Constructed wetland systems have advantages, such as low cost of construction and maintenance, low energy requirements, and they are less susceptible to variations in loading rate compared to conventional technical wastewater treatment systems (Kadlec et al., 2000; Kadlec and Wallace, 2009). Furthermore, constructed wetland systems can have multi-functions, including wildlife values and the production of usable plant biomass (Knight, 1997). Constructed wetland treatment systems generally fall into two categories: subsurface flow systems and free water surface flow system. Subsurface flow systems are designed with horizontal or vertical subsurface flow through a permeable medium (typically sand, gravel or crushed rock). Vertical flow systems can have unsaturated conditions in the media when the bed is drained, and saturated conditions when the effluent pipe is at level with the bed surface. Free water surface flow systems are shallow basins with water on the surface, and the treatment processes occur through complex interactions between the vegetation and the associated biofilms in the water phase. 


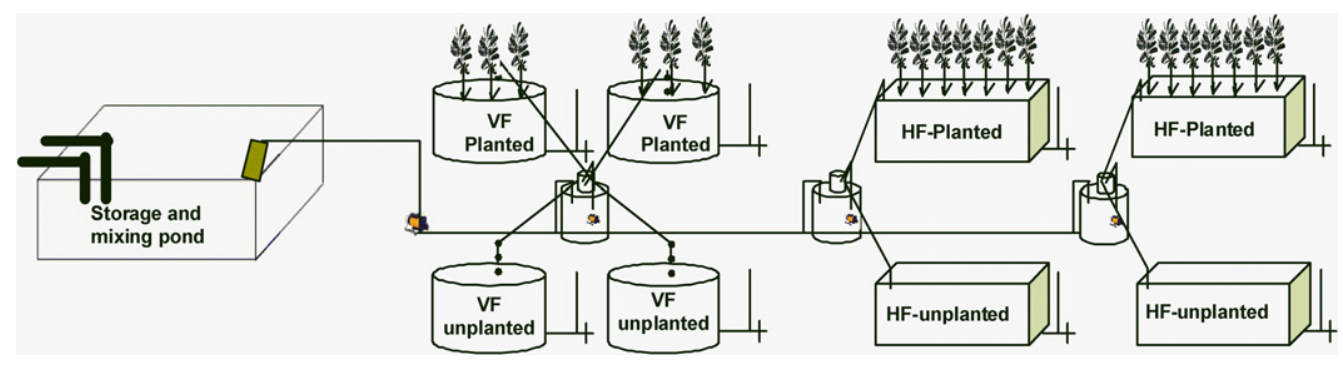

Fig. 1. Sketch of the experimental system showing the $10 \mathrm{~m}^{3}$ storage and mixing tank, the four vertical flow (VF) beds and the four horizontal flow (HF) beds.

The Mekong Delta in Vietnam is strongly based on agriculture, as $75 \%$ of the $40.000 \mathrm{~km}^{2}$ land is agricultural land. A large fraction of the population in the Delta (18 million) is farmers living in communities, which are split into small parcels along the waterways. Human organic sanitary waste as well as the excrements of pigs, poultry and other livestock is disposed mostly directly into the surface waters. However, as most of the local farmers depend on the surface water for drinking, irrigating their crops, fishing, and aquaculture, protection of this water source is crucial. The organic sanitary waste can be valuable when used for fertilizing soils for cropping or for growing fish, but may harm the environment, especially the water when discharged uncontrolled (Nhan et al., 2006, 2008).

Sesbania sesban is an atmospheric $\mathrm{N}_{2}$-fixing scrub that has both economic and biological values. It has a long history of agricultural use, primarily as green manures and as sources of forage (Evans et al., 1990). In Vietnam, leaves of Sesbania species are used as forage to supplement rice straw in the animal diet, and mulch for home gardens. In the Mekong Delta, S. sesban grows very fast in the wetland areas of the provinces of Dong Thap, Omon, Can Tho, Vinh Long and An Giang. Sesbania biomass decomposes rapidly due to the soft plant structure and high $\mathrm{N}$ content, and it provides nutrients to soil and other plants (Myers et al., 1994). In addition, Sesbania can bring income from wood, fodder or fruit products (Young, 1997).

The ability of $S$. sesban to grow at different ammonium $\left(\mathrm{NH}_{4}{ }^{+}\right)$ concentrations has been studied in soil culture, and it was shown that $S$. sesban seedlings can tolerate $\mathrm{NH}_{4}{ }^{+}$concentrations up to $800 \mathrm{mg} \mathrm{L}^{-1}$ (Indieka and Odee, 2005). In hydroponic culture, S. sesban grows well up to at least $70 \mathrm{mg} \mathrm{L}^{-1} \mathrm{NH}_{4}{ }^{+}$(Dan and Brix, 2009). This high tolerance towards exposure to $\mathrm{NH}_{4}{ }^{+}$suggests that $\mathrm{S}$. sesban has a potential for use in wastewater treatment systems.

This study was carried out to evaluate the potential of using S. sesban in constructed wetland systems treating high-strength wastewater. Two types of subsurface flow constructed wetlands with saturated water flow were studied: a horizontal subsurface flow (HF) system, and a saturated vertical downflow systems (VF). The performance of planted HF and VF systems versus unplanted controls was evaluated at three loading rates. Based on the performance data, removal rate constants were estimated and the growth and nutrient uptake of $S$. sesban calculated. The study aims to document for the first time that $S$. sesban can be used in constructed wetland systems for the treatment of high-strength wastewater while at the same time producing a valuable $\mathrm{N}$ rich biomass that can be used for animal fodder or soil amendment.

\section{Material and methods}

The research was carried out at a food animal processing company at Phung Hiep district, Hau Giang province, Vietnam $\left(9^{\circ} 48^{\prime} 21^{\prime \prime} \mathrm{N} ; 105^{\circ} 49^{\prime} 33^{\prime \prime} \mathrm{E}\right)$. The climate is tropical with high temperatures and high humidity. Wastewater from housings, including a small pig farm located at the company, was used as the source of wastewater for the study. An experimental system was set up in April 2007 to compare the performance of HF and VF constructed wetland systems, both with saturated media, as well as the effects of plants. The system consisted of four units of each CW type of which two were planted with S. sesban, and two were left unplanted (Fig. 1).

\subsection{The vertical flow system (VF)}

The VF units consisted of $1.13 \mathrm{~m}$ diameter plastic tanks installed with a $0.8 \mathrm{~m}$ deep vertical filter. The filters were built up, from the bottom, of $0.2 \mathrm{~m}$ of coarse gravel $(\varnothing 20-60 \mathrm{~mm}), 0.4 \mathrm{~m}$ of cracked coconut shells (size about $40 \mathrm{~mm}$ ) and $0.2 \mathrm{~m}$ of river sand $(\varnothing 0.5-1 \mathrm{~mm})$. The coconut shell and the sand layers were separated by a $0.05 \mathrm{~m}$ layer of gravel $(\varnothing 6-12 \mathrm{~mm}$ ) in order to prevent the sand from washing down into the coconut shell layer. Coconut shells, as a readily available waste product, were used to decrease costs of the systems. In the drainage layer, a $72 \mathrm{~mm}$ diameter drainage pipe was installed to collect the treated wastewater. The wastewater was loaded onto the surface of the filters through pipes with four holes placed at equal distances to distribute the water evenly over the surface. Loading of the water occurred in small batches to secure a good distribution of the water over the surface, and was obtained by $4 \mathrm{~L}$ siphons installed in the inlet line. The water level in the VF systems was kept $20 \mathrm{~mm}$ below the surface during the experiment by a vertical standpipe. Consequently the filters were saturated with water during operation. The porosity of the systems was about 35\% as estimated when filling the empty beds with water. Hence, the nominal residence times at the three hydraulic loading rates of 80,160 and $320 \mathrm{~mm} \mathrm{~d}^{-1}$ were $3.5,1.8$ and 0.9 days, respectively.

\subsection{The horizontal flow system (HF)}

The HF units were constructed as $5 \mathrm{~m} \times 1 \mathrm{~m} \times 1 \mathrm{~m}(L \times W \times D)$ concrete tanks with a bottom slope of $1 \%$ and installed with a $0.75 \mathrm{~m}$ deep horizontal filter. The filters were built up, from the bottom, of a $0.20 \mathrm{~m}$ layer of coarse gravel $(\varnothing 20-60 \mathrm{~mm})$, a $0.25 \mathrm{~m}$ layer of cracked coconut shells (size about $40 \mathrm{~mm}$ ), a $0.05 \mathrm{~m}$ layer of gravel (Ø6-12 mm), and a $0.3 \mathrm{~m}$ layer of sand $(\varnothing 0.5-1 \mathrm{~mm})$ at the top. Wastewater was distributed across the width of the systems at the inlet end by a $Ø 36 \mathrm{~mm}$ pipe, and effluent was collected from the bottom of the outlet end through a $\emptyset 72 \mathrm{~mm}$ drainage pipe. The water levels in the beds were controlled at $20 \mathrm{~mm}$ below the bed surface during operation by a vertical standpipe at the effluent end. The porosity of the systems was about $35 \%$. Hence, the nominal residence times at the three hydraulic loading rates of 80,160 and $320 \mathrm{~mm} \mathrm{~d}^{-1}$ were $3.3,1.6$ and 0.8 days, respectively. 


\subsection{Plant material}

S. sesban plants were produced from seeds in $1 \mathrm{~L}$ pots following the procedure described by Dan and Brix (2007). After 4 months, plants of a uniform size (cut down to about $850 \mathrm{~mm}$ height) were selected and planted at a density of $0.2 \mathrm{~m} \times 0.2 \mathrm{~m}$ (a total of 120 plants in each HF bed and 24 in each VF bed). During the initial 2 weeks, the plants were watered daily with dilute wastewater to stimulate plant establishment.

\subsection{The wastewater system}

A $350 \mathrm{~m}^{3}$ primary pond receiving the liquid manure from the pig farm as well as wastewater from the housing at the food processing industry was used as the source of wastewater for the experiment. The wastewater from the pond was pumped into a $10 \mathrm{~m}^{3}$ storage tank and here mixed with groundwater in a 1:1 ratio. The water from the storage tank was pumped to three 20 L dosing tanks placed at a higher elevation than the CW beds to allow for gravity feeding. The loading rate of the CW units was controlled by valves and timercontrolled pumps delivering water to the dosing tanks.

\subsection{Water and plant sampling}

Performance at three hydraulic loading rates (HLR) of 80, 160 and $320 \mathrm{~mm} \mathrm{~d}^{-1}$ was assessed in the system, starting at the low HLR of $80 \mathrm{~mm} \mathrm{~d}^{-1}$. The HLR was set by timer-controlled pumps and water meters and kept constant for at least 2 weeks before sampling. Then grab-samples of influent and effluent water from each bed were taken daily during five consecutive days. Water samples were collected in 1 Lglass bottles, transported to the laboratory and stored at $4{ }^{\circ} \mathrm{C}$ until analysis (usually within 3 days). After sampling at one loading rate, the HLR was increased to the next HLR, and the systems allowed to acclimate to this higher loading rate for at least 2 weeks before water samples were taken again during five consecutive days. The total number of water samples collected was 240 ( 3 HLRs $\times 5$ days $\times 8$ beds $\times 2$ sampling points, inlet and outlet). Sampling occurred during the dry period (December 2007 and January 2008). The effluent water quality at each 5-day sampling campaign was fairly constant indicating that the systems were in a steady state and that the acclimation period were long enough to allow the systems to adjust to the new loading rate.

The initial size of the plants was estimated by collecting 10 plants at random from the beds and measuring shoot height and biomass. After the last sampling campaign, 10 random plants were carefully dug out of the medium in each bed to estimate final biomass and growth rate. The length of the root system was measured with a ruler from the base to the tip of the longest root. Number of leaves were counted and the shoot height measured from the base of the shoot to the tip of the longest shoot. Harvested plants were fractionated into leaves, stems and roots and their fresh weight (FW) and dry weight (DW) measured after drying to constant weight in a $60^{\circ} \mathrm{C}$ ventilated oven. A total of 50 plants were sampled (10 initially and 10 plants from each of four planted beds at the end).

\subsection{Chemical analysis}

The water samples were analysed for temperature, $\mathrm{pH}$, electric conductivity (EC), dissolved oxygen (DO), turbidity, chemical oxygen demand (COD), biochemical oxygen demand $\left(\mathrm{BOD}_{5}\right)$, ammonium nitrogen $\left(\mathrm{NH}_{4}-\mathrm{N}\right)$, nitrate nitrogen $\left(\mathrm{NO}_{3}-\mathrm{N}\right)$, total nitrogen (TN) and total phosphorus (TP). Temperature, pH, EC, DO and turbidity were measured in the field by a Pioneer 10, 20, 30 portable analyser (Radiometer Analytical SAS, France). COD
Table 1

Average $( \pm S D)$ composition of the wastewater loaded into the experimental system during three loading campaigns $(n=40)$.

\begin{tabular}{lccc}
\hline \multirow{2}{*}{ Parameters } & \multicolumn{3}{l}{ Hydraulic loading rate } \\
\cline { 2 - 4 } & $80 \mathrm{~mm} \mathrm{~d}^{-1}$ & $160 \mathrm{~mm} \mathrm{~d}^{-1}$ & $320 \mathrm{~mm} \mathrm{~d}^{-1}$ \\
\hline Turbidity (NTU) & $36 \pm 7$ & $71 \pm 2$ & $85 \pm 1$ \\
$\mathrm{BOD}\left(\mathrm{mg} \mathrm{L}^{-1}\right)$ & $28 \pm 2$ & $71 \pm 2$ & $83 \pm 2$ \\
$\mathrm{COD}\left(\mathrm{mg} \mathrm{L}^{-1}\right)$ & $126 \pm 11$ & $205 \pm 2$ & $264 \pm 3$ \\
$\mathrm{NH}_{4}-\mathrm{N}\left(\mathrm{mg} \mathrm{L}^{-1}\right)$ & $163 \pm 17$ & $224 \pm 4$ & $312 \pm 1$ \\
$\mathrm{NO}_{3}-\mathrm{N}\left(\mathrm{mg} \mathrm{L}^{-1}\right)$ & $3.1 \pm 0.3$ & $4.2 \pm 0.2$ & $5.9 \pm 0$ \\
Total-N $\left(\mathrm{mg} \mathrm{L}^{-1}\right)$ & $478 \pm 23$ & $603 \pm 2$ & $703 \pm 3$ \\
Total-P $\left(\mathrm{mg} \mathrm{L}^{-1}\right)$ & $135 \pm 6$ & $145 \pm 9$ & $143 \pm 1$ \\
$\mathrm{pH}$ & $7.75 \pm 0.07$ & $8.26 \pm 0.04$ & $8.87 \pm 0.02$ \\
$\mathrm{DO}\left(\mathrm{mg} \mathrm{L}^{-1}\right)$ & $0.47 \pm 0.04$ & $0.12 \pm 0.01$ & $0.08 \pm 0.01$ \\
$\mathrm{EC}\left(\mathrm{mS} \mathrm{cm}^{-1}\right)$ & $1.0 \pm 0.2$ & $1.7 \pm 0.1$ & $2.5 \pm 0.1$ \\
\hline
\end{tabular}

was analysed by the $\mathrm{K}_{2} \mathrm{Cr}_{2} \mathrm{O}_{7}$ method according to APHA (1998). $\mathrm{BOD}_{5}$ was analysed by the OxiTop system (WTW GmbH, Weilheim, Germany). $\mathrm{NH}_{4}-\mathrm{N}$ and $\mathrm{NO}_{3}-\mathrm{N}$ were analysed on $\mathrm{GF} / \mathrm{C}$-filtered samples by colorimetric methods (Lachat Instruments, Milwaukee, WI, USA), and TN and TP were analysed following standard methods (APHA, 1998). The dried plant samples were finely ground with a ball mill grinder and the contents of TN and TP analysed after acid digestion in $\mathrm{H}_{2} \mathrm{SO}_{4}$ and $\mathrm{H}_{2} \mathrm{O}_{2}(3: 1)$ at $350^{\circ} \mathrm{C}$ following standard methods (APHA, 1998).

\subsection{Removal rate constants}

First-order area-based removal rate constants, assuming exponential removal, were calculated for BOD, COD, TN, $\mathrm{NH}_{4}{ }^{+}$and TP using the following equation (Kadlec and Knight, 1996): $K=$ HLR $\left(\ln C_{\text {in }}-\ln C_{\text {out }}\right)$ where $K$ is the area-based first-order removal rate constant $\left(\mathrm{m}_{\text {year }}{ }^{-1}\right.$ ), HLR is the mean hydraulic loading rate for the given monitoring period $\left(\mathrm{myear}^{-1}\right), C_{\text {in }}$ is the inlet concentration $\left(\mathrm{mg} \mathrm{L}^{-1}\right)$, and $C_{\text {out }}$ is the outlet concentration $\left(\mathrm{mg} \mathrm{L}^{-1}\right)$. We did not include the irreducible background wetland concentration $\left(C^{*}\right)$ in the equation as we did not have reliable estimates of $C^{*}$.

\subsection{Statistics}

All statistics were carried out using the software Statgraphics Centurion ver 15.2 (Manugistics, Inc., MD, USA). Data were tested for normal distribution and variance homogeneity using Kolmogorov-Smirnov test and Levene's tests, and if necessary log-transformed to ensure homogeneity of variances. The General Linear Models (GLM) procedure was used to analyse the data with system type (VF and HF), plant (planted versus unplanted) and HLR $\left(80,160\right.$ and $\left.320 \mathrm{~mm} \mathrm{~d}^{-1}\right)$ as fixed factors and sampling campaign as a random factor nested within system type and plant. Differences between individual means were identified using Tukey HSD procedure at the $5 \%$ significance level.

\section{Results}

\subsection{Inlet water quality}

The composition of the wastewater that was loaded into the experimental beds changed during the experiment and became more concentrated towards the end of the study (Table 1 and Fig. 2). The experiment was initiated during the rainy season which caused more rainwater to enter the wastewater pond during the first part of the study compared to later. Even though we attempted to obtain an equal strength of the wastewater by mixing it with groundwater in the $10 \mathrm{~m}^{3}$ storage tank, the contents of pollutants, particularly COD and $\mathrm{N}$, were about twice as high at the $320 \mathrm{~mm} \mathrm{~d}^{-1}$ 

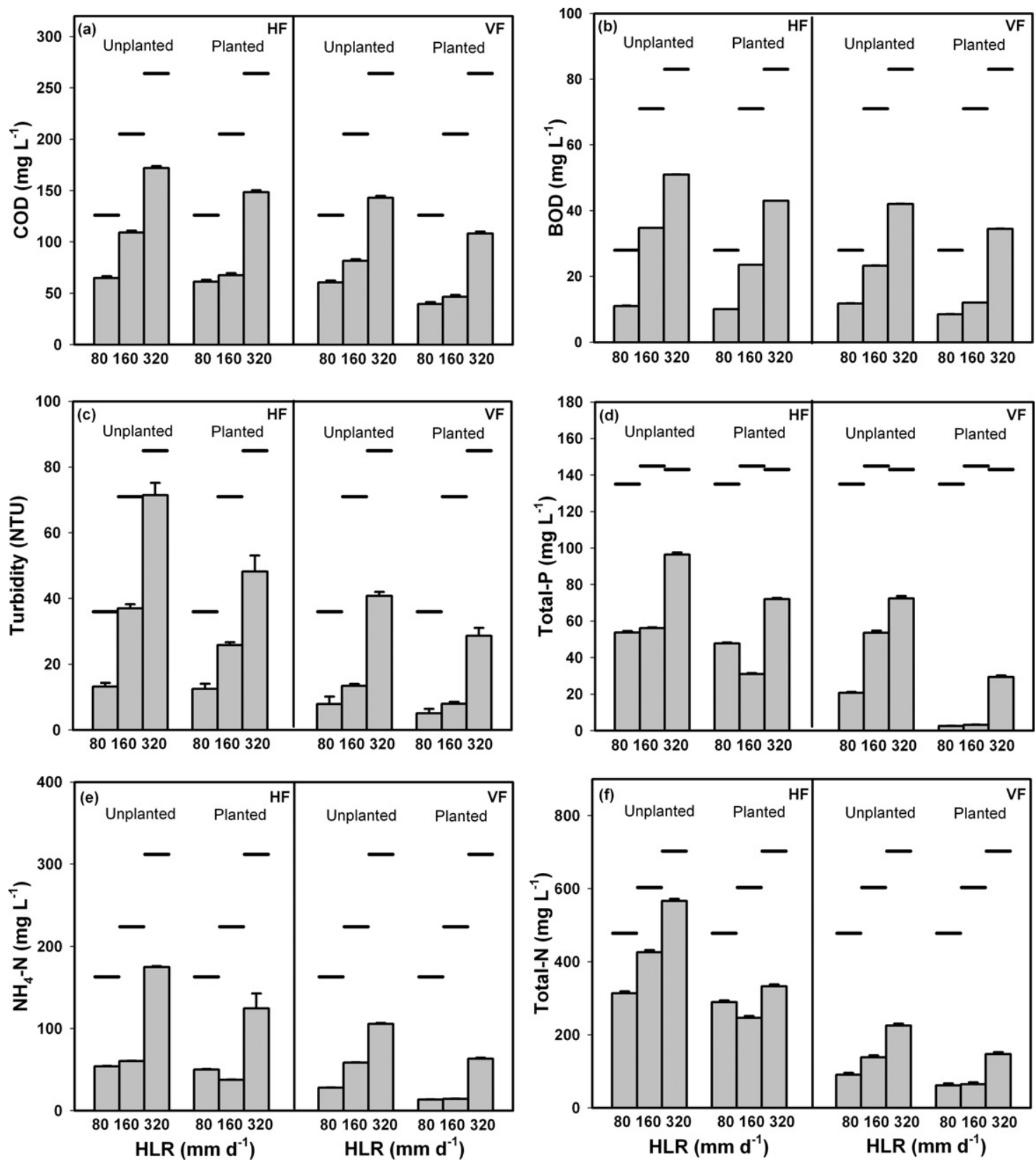

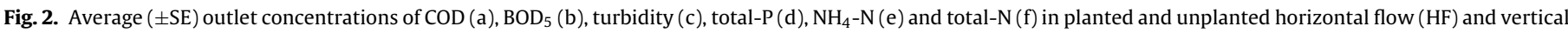
downflow (VF) constructed wetland beds at three hydraulic loading rates. Average inlet concentrations are shown as black bars over the columns.

HLR compared to $80 \mathrm{~mm} \mathrm{~d}^{-1}$ HLR. Hence, the influent mass loadings were about $8 \times$ higher for $320 \mathrm{~mm} \mathrm{~d}^{-1}$ HLR compared to $80 \mathrm{~mm} \mathrm{~d}^{-1}$ HLR for these compounds. The concentrations of $\mathrm{N}$ and $\mathrm{P}$ in the wastewater were nearly 10 times higher than the levels in 'normal' domestic sewage, whereas BOD and COD levels were in the range expected in partly decomposed domestic sewage. There were no significant $(P>0.05)$ differences in the composition of the wastewater loaded into the different systems.

\subsection{Effluent water quality}

The effluent concentrations of all measured parameters differed significantly between type of system and loading rate, and the effects of loading rate on effluent concentration of all parameters, except TN, differed between the systems as shown by significant interactions in the GLM analysis (Table 2). Also, there was a signifi- cant effect of plants for all parameters, and a significant interaction between system type and plant for all parameters, except $\mathrm{NO}_{3}{ }^{-}$and $\mathrm{pH}$. The effects of plants differed between loading rates as shown by significant interactions between loading and plant in the GLM analysis for all parameters.

The $\mathrm{pH}$ of the water decreased by passing through the CW beds and more so in VF beds (average $0.9 \mathrm{pH}$ units) than in HF beds (average $0.6 \mathrm{pH}$ unit) (data not shown). The DO increased slightly from 0.2 to $2.0 \mathrm{mg} \mathrm{L}^{-1}$ in VF beds and from 0.2 to $1.5 \mathrm{mg} \mathrm{L}^{-1}$ in $\mathrm{HF}$ beds, and increased more in planted VF beds than in unplanted (data not shown). The effluent from the VF beds was generally less turbid than that of the HF beds, but turbidity in the effluent increased with loading rate (Fig. 2c). Effluent BOD concentrations from the VF beds were $9-11 \mathrm{mg} \mathrm{L}^{-1}$ at a HLR of $80 \mathrm{~mm} \mathrm{~d}^{-1}$ and increased to $35-42 \mathrm{mg} \mathrm{L}^{-1}$, lowest in the planted beds, at a HLR of $320 \mathrm{~mm} \mathrm{~d}^{-1}$ (Fig. 2b). In the HF flow beds, the BOD effluent concentrations were 
Table 2

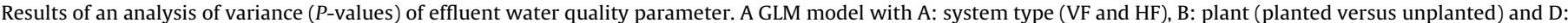

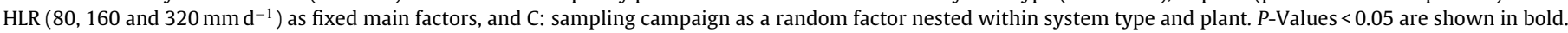
$D f=$ degrees of freedom.

\begin{tabular}{|c|c|c|c|c|c|c|c|}
\hline Parameter & A: System $(D f=1)$ & B: Plant $(D f=1)$ & $\mathrm{A} \times \mathrm{B}(D f=1)$ & C: Campaign $(\mathrm{A} \times \mathrm{B})(D f=4)$ & $\mathrm{D}: \operatorname{HLR}(D f=2)$ & $\mathrm{A} \times \mathrm{D}(D f=2)$ & $\mathrm{B} \times \mathrm{D}(D f=2)$ \\
\hline Turbidity & 0.0000 & 0.0000 & 0.0019 & 0.9582 & 0.0000 & 0.0000 & 0.0001 \\
\hline BOD & 0.0000 & 0.0000 & 0.3612 & - & 0.0000 & 0.0000 & 0.0000 \\
\hline COD & 0.0000 & 0.0000 & 0.0021 & 0.9828 & 0.0000 & 0.0016 & 0.0004 \\
\hline $\mathrm{NH}_{4}-\mathrm{N}$ & 0.0000 & 0.0000 & 0.0139 & 0.9316 & 0.0000 & 0.0000 & 0.0001 \\
\hline $\mathrm{NO}_{3}-\mathrm{N}$ & 0.0000 & 0.0000 & 0.1241 & 0.9861 & 0.0000 & 0.0044 & 0.0000 \\
\hline Total-N & 0.0000 & 0.0000 & 0.0001 & 0.9954 & 0.0000 & 0.3667 & 0.0016 \\
\hline Total-P & 0.0000 & 0.0000 & 0.0000 & 0.9975 & 0.0000 & 0.0000 & 0.0000 \\
\hline $\mathrm{pH}$ & 0.0004 & 0.0000 & 0.4100 & 0.6132 & 0.0000 & 0.0280 & 0.0000 \\
\hline DO & 0.0000 & 0.0000 & 0.0001 & 0.9614 & 0.0000 & 0.0043 & 0.0044 \\
\hline EC & 0.0001 & 0.0015 & 0.0265 & 0.2941 & 0.0000 & 0.0001 & 0.0001 \\
\hline
\end{tabular}

generally higher than from the VF beds with the exception of the HLR ( $\left.80 \mathrm{~mm} \mathrm{~d}^{-1}\right)$ at which both bed types were similar (Fig. 2b). The general pattern for COD was similar to that of BOD with lower effluent concentrations from the VF beds and slightly lower concentrations from planted beds (Fig. 2a). Effluent concentrations of TP were two-factor higher in the effluent from HF beds (ca. $60 \mathrm{mg} \mathrm{L}^{-1}$ ) than VF beds (ca. $30 \mathrm{mg} \mathrm{L}^{-1}$ ) (Fig. 2d). There was a very significant effect of plants on effluent $P$ concentration in both types of systems, but most so for the VF system. Effluent concentrations of both TN and $\mathrm{NH}_{4}-\mathrm{N}$ were also significantly lower in the VF systems than in the HF systems, and the effects of plants were also apparent (Fig. 2e and f).

\subsection{Mass removals}

The mass loading rates reached levels of: BOD 27, COD 85, TN 225, $\mathrm{NH}_{4}-\mathrm{N} 99$ and TP $46 \mathrm{~g} \mathrm{~m}^{-2} \mathrm{~d}^{-1}$ at the highest HLR, and did not differ significantly between the beds. The maximum mass removal rates at the highest HLR were: BOD 16, COD 50, TN 178, $\mathrm{NH}_{4}{ }^{+}-\mathrm{N} 80$ and TP $36 \mathrm{~g} \mathrm{~m}^{-2} \mathrm{~d}^{-1}$ in the planted VF beds, while the maximum mass removal rates were lower in the planted HF beds: BOD 13 , COD 37, TN 119, $\mathrm{NH}_{4}-\mathrm{N} 58$ and TP $23 \mathrm{~g} \mathrm{~m}^{-2} \mathrm{~d}^{-1}$.

In Fig. 3 the mass removal rates are plotted against the mass loading rates of COD, BOD, TP, $\mathrm{NH}_{4}-\mathrm{N}$ and TN. The lines in the plots represent total removal. As expected, the mass removal rates increased with mass loading rates, and there was a tendency for the mass removal rates to level off at high mass loadings. Furthermore, the mass removal rates generally were higher in VF systems compared to HF systems, and higher in planted beds than in the unplanted beds, especially at higher influent loadings.

Removal efficiencies were higher in VF systems compared with HF systems (Fig. 4). The average removal efficiencies of COD, BOD and TP were 68,72 , and $92 \%$, respectively. The removal efficiencies of TN and $\mathrm{NH}_{4}-\mathrm{N}$ at a HLR of $160 \mathrm{~mm} \mathrm{~d}^{-1}$ in the VF system were 85 and $88 \%$, respectively. As expected, the removal efficiency of all parameters decreased with increasing HLR. Comparison of removal efficiencies between planted and unplanted beds show that for all pollutants, the removal efficiencies were higher in planted beds than in the unplanted beds (Fig. 4).

\subsection{Removal rate constants}

Removal rate constants differed significantly between type of system and increased with loading rate, but the effects of loading rate differed between systems as shown by significant interactions in the GLM analysis (Table 3). There were also significant interactions between plant and loading, and plant and system, showing that plants had a significant effect on the removal rate constants. Removal rate constants were generally much higher at high loading rates (Fig. 5).

$K_{\text {COD }}$ in planted VF systems ranged between 33 and $104 \mathrm{~m}$ year $^{-1}$, lowest at a HLR of $80 \mathrm{~mm} \mathrm{~d}^{-1}$ in both systems and highest in the planted VF system at a HLR of $320 \mathrm{~mm} \mathrm{~d}^{-1}$ (Fig. 5a). $K_{\mathrm{COD}}$ for planted HF were similar at 160 and $320 \mathrm{~mm} \mathrm{~d}^{-1}$, indicating a maximum reaction rate was reached at about 70 mear $^{-1}$. The pattern for $K_{\mathrm{BOD}}$ was similar in planted HF beds with values ranging between 25 and 75 mear $^{-1}$ (Fig. 5b). A maximum $K_{\mathrm{BOD}}$ of about 100 mear $^{-1}$ seems to have been observed for planted VF systems ( 160 and $320 \mathrm{~mm} \mathrm{~d}^{-1}$ the same). The removal rate constant for total-P, $K_{\mathrm{TP}}$, was much lower in unplanted beds compared with planted beds, and higher in VF systems than HF systems (Fig. 5c). The maximum $K_{\mathrm{TP}}\left(224 \mathrm{~m}_{\text {year }}{ }^{-1}\right.$ ) was recorded in the planted VF systems at a HLR of $320 \mathrm{~mm} \mathrm{~d}^{-1}$. The removal rate constants for $\mathrm{NH}_{4}-\mathrm{N}$ and TN were generally twice as high in the VF systems compared to the HF systems (Fig. $5 \mathrm{~d}$ and e). $K_{\mathrm{TN}}$ was relatively low in the unplanted HF at all HLRs, indicating an importance of plants for TN removal in such systems. The maximum value of $K_{\mathrm{NH} 4}$ and $K_{\mathrm{TN}}$ were 186 and 183 m year $^{-1}$, respectively, in the planted VF system.

\subsection{Plant growth and nutrient uptake}

Plants grew best in the VF beds compared to the HF beds, but the root to shoot ratio did not differ between the two types of systems (Table 4). Other growth parameters like root elongation rate, shoot elongation rate, leaf production rate and biomass production were generally $1.17-1.25$ times higher in the VF systems compared to the HF systems. Nitrogen concentrations in the S. sesban biomass were relatively high in general (Table 5). The plants in the VF beds contained higher concentrations of $\mathrm{N}$ and $\mathrm{P}$ in their tissues com-

Table 3

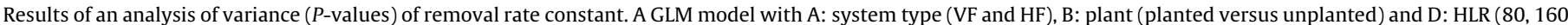

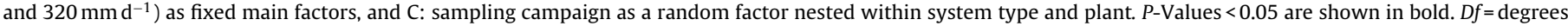
of freedom.

\begin{tabular}{|c|c|c|c|c|c|c|c|}
\hline Parameter & A: System $(D f=1)$ & B: Plant $(D f=1)$ & $\mathrm{A} \times \mathrm{B}(D f=1)$ & C: Campaign $(\mathrm{A} \times \mathrm{B})(D f=4)$ & D: $\operatorname{HLR}(D f=2)$ & $\mathrm{A} \times \mathrm{D}(D f=2)$ & $\mathrm{B} \times \mathrm{D}(D f=2)$ \\
\hline$K_{\mathrm{BOD}}$ & 0.0000 & 0.0000 & 0.0028 & - & 0.0000 & 0.0000 & 0.0000 \\
\hline$K_{\mathrm{COD}}$ & 0.0000 & 0.0000 & 0.0890 & 0.7086 & 0.0000 & 0.0000 & 0.0000 \\
\hline$K_{\mathrm{NH} 4}$ & 0.0001 & 0.0001 & 0.5576 & 0.6385 & 0.0000 & 0.0000 & 0.0000 \\
\hline$K_{\mathrm{TN}}$ & 0.0000 & 0.0000 & 0.0000 & 0.9986 & 0.0000 & 0.0000 & 0.0007 \\
\hline$K_{\mathrm{TP}}$ & 0.0000 & 0.0000 & 0.0001 & 0.9652 & 0.0000 & 0.0000 & 0.0000 \\
\hline
\end{tabular}



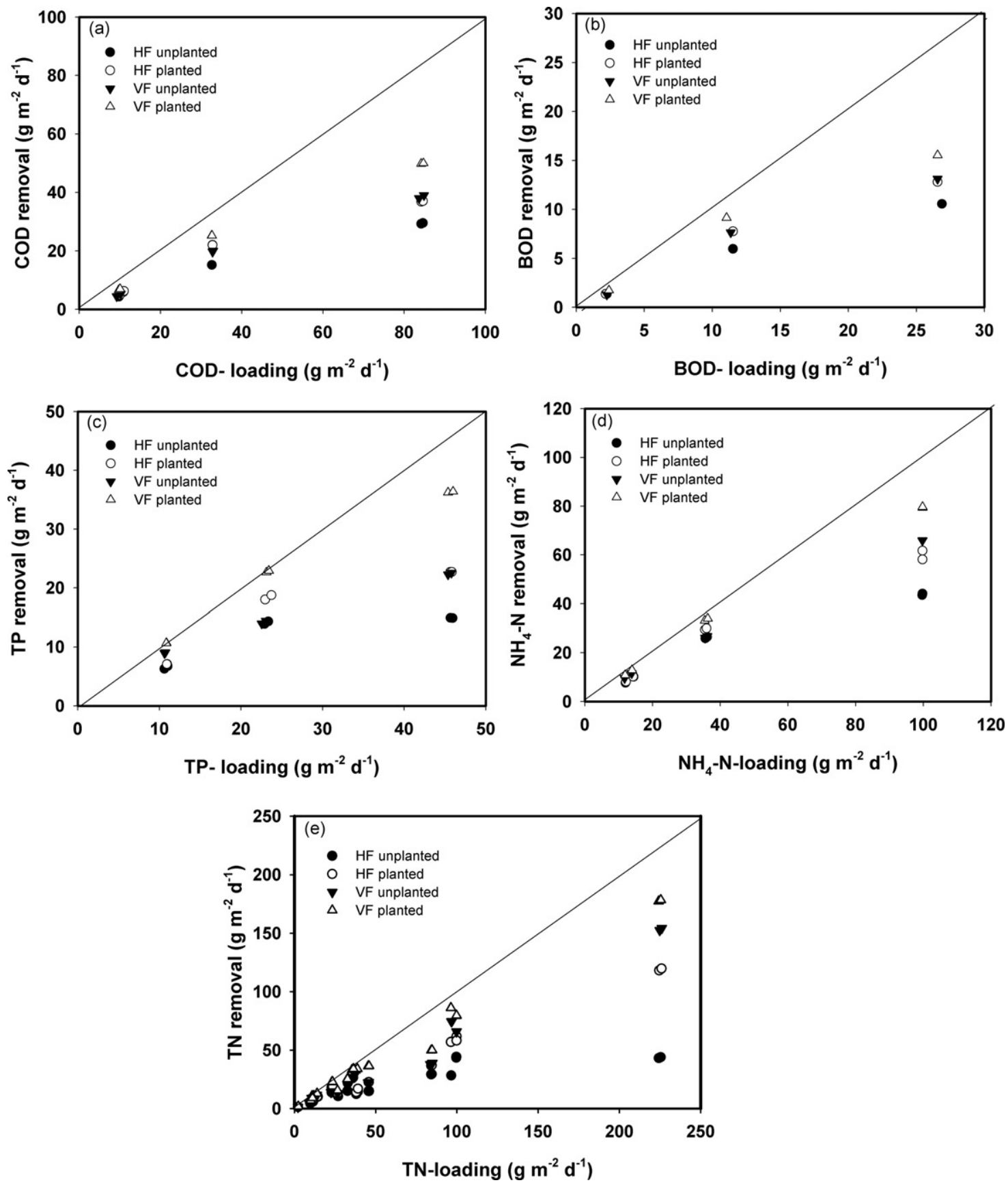

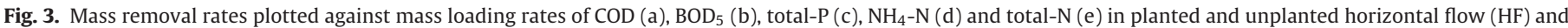
vertical downflow (VF) constructed wetland beds at three hydraulic loading rates. The lines in the plots represent total removal.

Table 4

Growth characteristic of Sesbania sesban in horizontal flow and vertical flow systems $($ mean \pm SE).

\begin{tabular}{lcc}
\hline Parameters & Horizontal flow & Vertical flow \\
\hline Relative growth rate $\left(\mathrm{d}^{-1}\right)$ & $0.04 \pm 0.01^{\mathrm{a}}$ & $0.06 \pm 0.01^{\mathrm{b}}$ \\
Root elongation rate $\left(\mathrm{cm} \mathrm{d}^{-1}\right)$ & $0.54 \pm 0.02^{\mathrm{a}}$ & $0.68 \pm 0.02^{\mathrm{b}}$ \\
Shoot elongation rate $\left(\mathrm{cm} \mathrm{d}^{-1}\right)$ & $3.1 \pm 0.1^{\mathrm{a}}$ & $3.6 \pm 0.1^{\mathrm{b}}$ \\
Leaf production rate $\left(\mathrm{No} \mathrm{d}^{-1}\right)$ & $1.6 \pm 0.1^{\mathrm{a}}$ & $2.4 \pm 0.1^{\mathrm{b}}$ \\
Root to shoot ratio & $0.31 \pm 0.01$ & $0.32 \pm 0.01$ \\
Root dry weight $(\mathrm{g})$ & $20.9 \pm 0.6^{\mathrm{a}}$ & $24.4 \pm 0.6^{\mathrm{b}}$ \\
Leaf dry weight $(\mathrm{g})$ & $8.7 \pm 0.2^{\mathrm{a}}$ & $10.9 \pm 0.2^{\mathrm{b}}$ \\
Shoot dry weight $(\mathrm{g})$ & $66 \pm 1^{\mathrm{a}}$ & $75 \pm 1^{\mathrm{b}}$ \\
\hline
\end{tabular}

Means with different superscripts ( $a$ and $b$ ) in the same row differ significantly $(P<0.05)$.
Table 5

Total-N and total-P concentrations in roots, stem and leaf fractions of Sesbania sesban from horizontal flow and vertical flow systems (mean \pm SE).

\begin{tabular}{lll}
\hline & Horizontal flow & Vertical flow \\
\hline $\begin{array}{l}\text { Total-N (\% DW) } \\
\text { Roots }\end{array}$ & $3.05 \pm 0.01^{\mathrm{a}}$ & \\
$\quad$ Stems & $2.09 \pm 0.01^{\mathrm{a}}$ & $3.32 \pm 0.05^{\mathrm{b}}$ \\
$\quad$ Leaves & $5.51 \pm 0.09^{\mathrm{a}}$ & $6.17 \pm 0.03^{\mathrm{b}}$ \\
Total-P $\left(\mathrm{mg} \mathrm{g}^{-1} \mathrm{DW}\right)$ & & \\
$\quad$ Roots & $3.19 \pm 0.19^{\mathrm{a}}$ & $4.33 \pm 0.04^{\mathrm{b}}$ \\
Stems & $2.21 \pm 0.03^{\mathrm{a}}$ & $3.63 \pm 0.05^{\mathrm{b}}$ \\
Leaves & $5.31 \pm 0.04^{\mathrm{a}}$ & $6.09 \pm 0.01^{\mathrm{b}}$
\end{tabular}

Means with different superscripts ( $a$ and $b$ ) in the same row differ significantly $(P<0.05)$. 

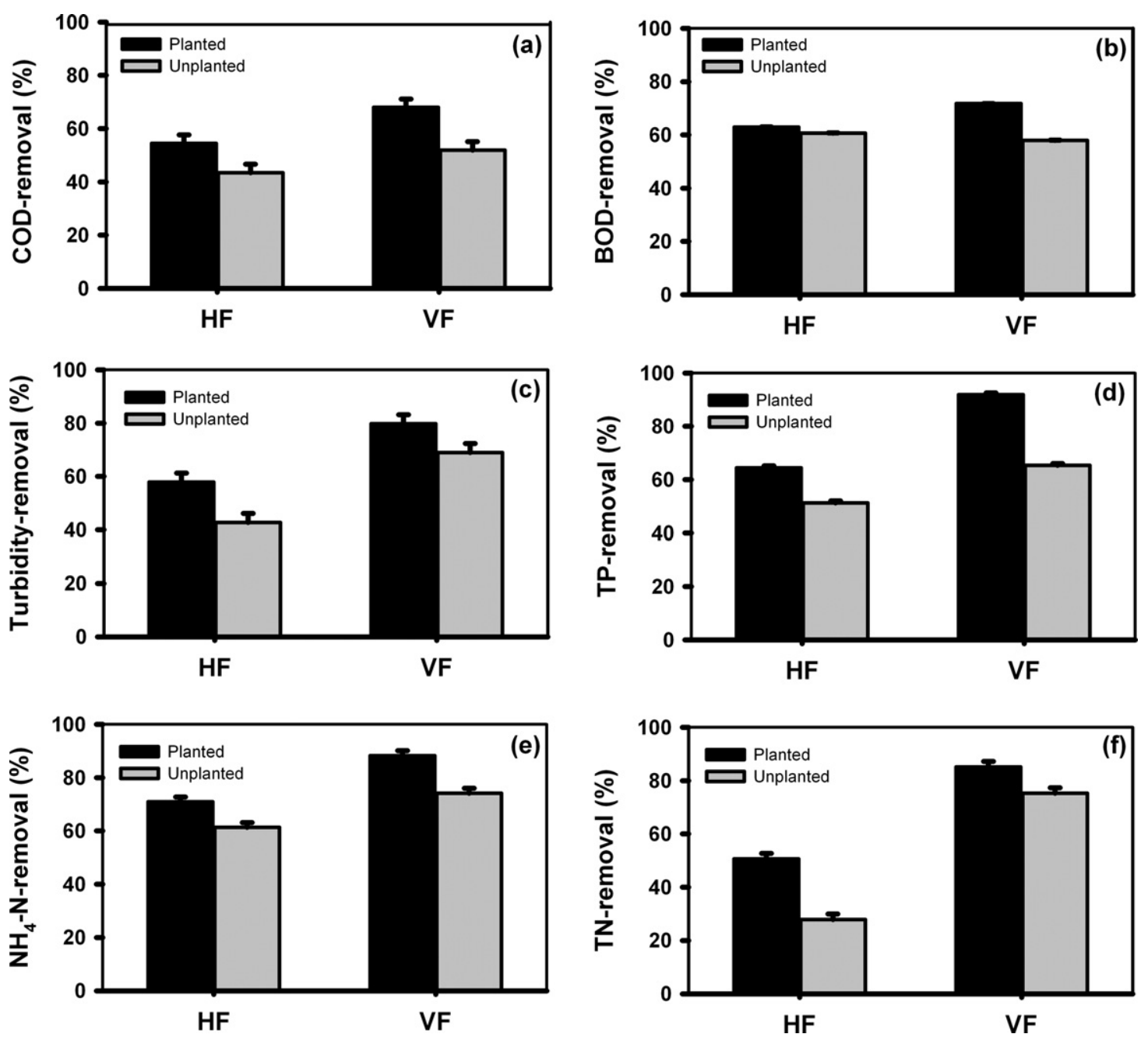

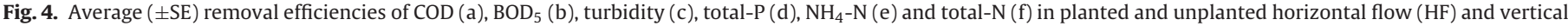
downflow (VF) constructed wetland systems.

pared to plants from the HF system. The dry biomass production in the two systems during the experimental period were 20.2 and $17.2 \mathrm{~kg} \mathrm{~m}^{-2}$ year $^{-1}$ for the VF and HF system, respectively.

Using the biomass production rates and the tissue $\mathrm{N}$ and $\mathrm{P}$ concentrations, the plant uptake of $\mathrm{N}$ was estimated to be 2.26 and $1.27 \mathrm{~g} \mathrm{~m}^{-2} \mathrm{~d}^{-1}$ for the VF and HF systems, respectively, and the plant uptake of $P$ was estimated to be 0.23 and $0.13 \mathrm{~g} \mathrm{~m}^{-2} \mathrm{~d}^{-1}$ for the VF and HF systems, respectively. Comparing the plant uptake of $\mathrm{N}$ with the mass removal rates in the system, it can be seen that the plant uptake constituted between 1.1 and $8.2 \%$ of $\mathrm{N}$ mass removal and between 0.6 and $2.2 \%$ of $P$ mass removal, highest at low loading rates and in the VF systems.

\section{Discussion}

The S. sesban plants grew very well in the constructed wetland system in spite of the high loadings with high-strength wastewater. As $S$. sesban is a valuable species used for many purposes in tropical areas, including fodder for animals and mulch for homegardens, the incentive to use $S$. sesban in constructed wetland systems may be high as compared to use of other non-use wetland plants. The $\mathrm{N}$ concentrations of the plant tissues were high: approx. 6\% in leaves, $4 \%$ in roots and $3 \%$ in stems, showing the high nutritive value of the plant tissue. Combined with the high growth and biomass production of $S$. sesban in the systems, this documents the high potential of using S. sesban for the treatment of wastewater in constructed wetland systems while simultaneously producing a useable crop. In addition, $S$. sesban significantly improved the treatment performance of the constructed wetland systems as compared to the unplanted controls.

Both mass removal rates and the estimated removal rate constants increased with loading rate, but for some parameters the rate constants were nearly similar at HLRs of 160 and $320 \mathrm{~mm} \mathrm{~d}^{-1}$, indicating a maximum reaction rate was reached. This is supported by the fact that, at the highest loading rate, the effluent quality severely deteriorated resulting in unacceptable high pollutant levels, and that hydraulic problems resulting in surface flow started to appear. Therefore, the very high removal constants estimated at the highest loading rate of $320 \mathrm{~mm} \mathrm{~d}^{-1}$ should not be used for future designs. Rather, the rate constants at the intermediate HLR of $160 \mathrm{~mm} \mathrm{~d}^{-1}$ might be used as an indication of what removal rates can be expected, under due consideration to the type of wastewater. The removal rate constants for BOD and COD were high: $K_{\mathrm{BOD}} 102$ and 65 myear $^{-1}$ for planted VF and HF systems, respectively, and $K_{\mathrm{COD}} 86$ and $64 \mathrm{myear}^{-1}$ for planted VF and HF systems, respectively. This is in the higher range of $K$-values reported in the literature, probably partially because of the higher temperature (Kadlec and Knight, 1996; Knight et al., 2000; Oovel et al., 2007; Konnerup et al., 2009; Kantawanichkul et al., 2009; Kadlec and Wallace, 2009). We did not include the irreducible back- 

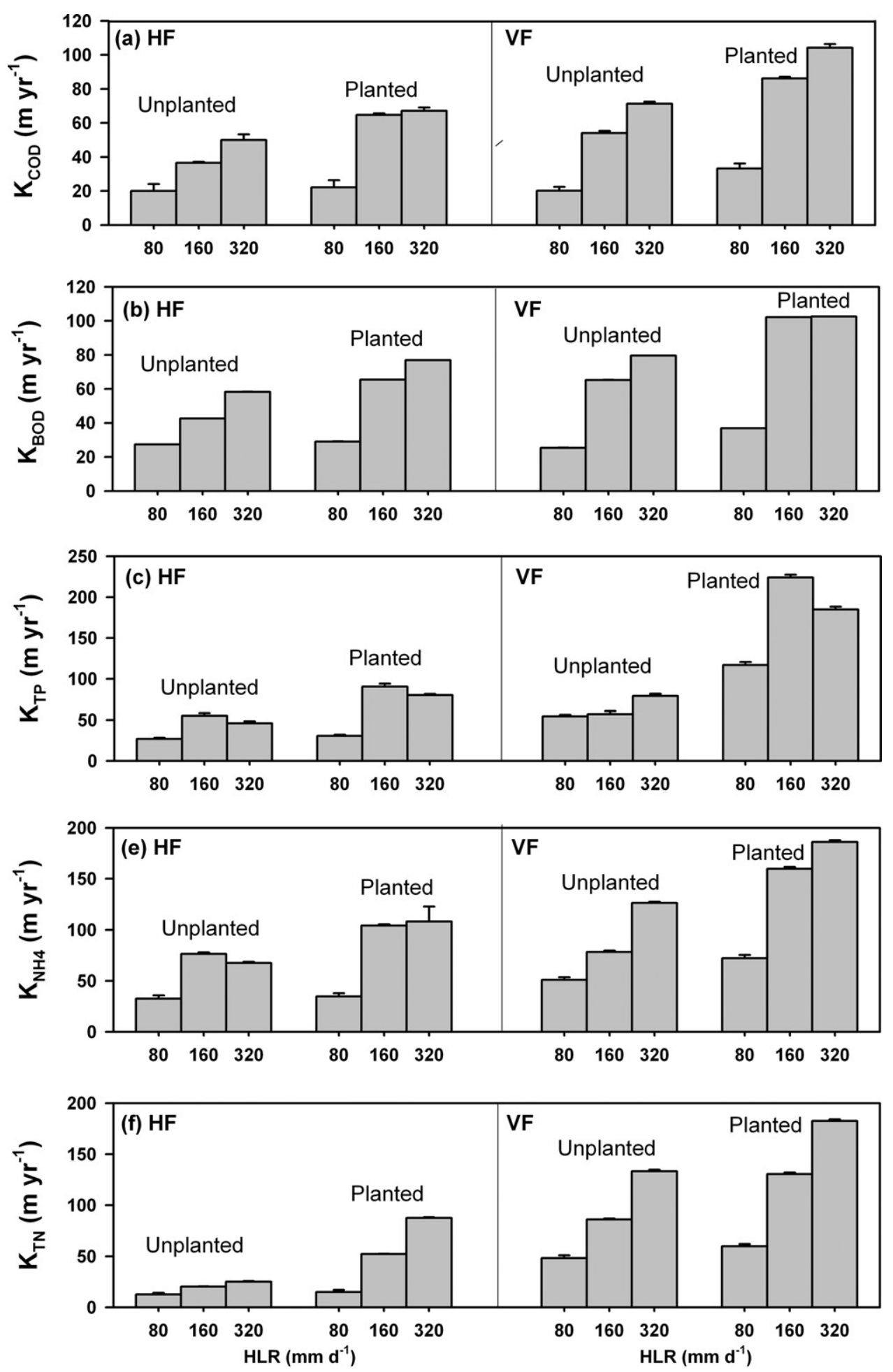

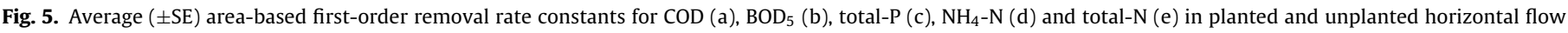
(HF) and vertical downflow (VF) constructed wetland beds at three hydraulic loading rates.

ground wetland concentration $\left(C^{*}\right)$ in the model used to estimate $K$-values in the present study, as we did not have a reliable estimate of $C^{*}$. $K$-Rates estimated from the $K-C^{*}$ model tend to result in higher $K$-values than the model that does not include $C^{*}$. Therefore, the $K$-rates derived in the present study should not be used in a $K-C^{*}$ model for the design of a treatment system. Additional studies aiming at estimating the irreducible background concentration $\left(C^{*}\right)$ are needed to better estimate $K$-values of the constructed wetland systems under tropical conditions.

The VF beds generally performed better than the HF beds. As both types of beds had saturated flow, the better performance of the VF systems were probably related to the hydraulics of the system. Before planting, we did conduct tracer tests using $\mathrm{NaCl}$ and electric conductivity (EC) to estimate the retention time distribu- 
tion of 2 HF systems and 2 VF systems. However, because of heavy rain during the tests, the data did not allow us to quantify the retention time distributions of the systems. However, the tracer tests indicated that the coarse layers in the HF beds with high hydraulic conductivity acted as a shortcut for water to pass quickly to the outlet. In the VF beds this was not observed. The generally better treatment performance of VF beds as compared to HF beds therefore seems to be related to a better hydraulic efficiency of the filters and to the presence of the small sand layer at the top of the filter and the consequent better filtration capacity.

Mass removal rates and removal rate constants for $\mathrm{NH}_{4}$ $\mathrm{N}$ removal as well as TN removal were exceptional high and higher than reported in the literature, probably because of the high-strength wastewater, the high loading rates and the tropical conditions. The short-term nature of the monitoring might, however, also have influenced the results. Removal of P was, unexpectedly, relatively high in the system, particularly in the planted beds with vertical downflow. We expected the gravel, sand and cracked coconut material used in the bed medium to have a low binding capacity for P. However, we did not study that. The proportion of $P$ taken up by the plants constituted less than $2.2 \%$ of the $P$ removal showing that plant uptake of $P$ was not quantitatively significant. The relatively efficient $P$ removal in the systems can only be explained by accumulation in the bed medium of sludge and mineral particles and by adsorption to the bed medium. The high strength of the wastewater probably also influenced performance. The average mass removal rates of $P$ at a HLR of $160 \mathrm{~mm} \mathrm{~d}^{-1}$ for planted VF and HF systems were 22.8 and $18.4 \mathrm{~g} \mathrm{~m}^{-2} \mathrm{~d}^{-1}$, respectively, and the removal rate constants were 90 and 224 m year $^{-1}$, respectively, which is much higher than reported in other studies (Kadlec and Knight, 1996; Oovel et al., 2007).

Nitrogen processing in the wetland was high, but not complete, as the concentrations in the effluent were still high. Because of the water saturated conditions in both types of systems, nitrification was probably negligible. In vertical flow constructed wetland systems with unsaturated flow, as used in several other studies, the aeration of the filter medium is much better providing good conditions for ammonia oxidizing bacteria. It would be interesting in future studies to evaluate the performance of unsaturated vertical filters particularly for $\mathrm{N}$ processing, as the nitrification and hence $\mathrm{N}$ removal would be expected to be even more efficient. However, the physical structure of the vertical filter should allow the water to be held in the filter long enough to allow adequate contact with the bacteria growing on the surface of the gravel to secure both ammonification and nitrification. The filters used in the present study were relative shallow (ca. $0.8 \mathrm{~m}$ ) and consisted of coarser materials compared with unsaturated vertical flow systems used in temperate regions (Brix and Arias, 2005a,b). Ammonia volatilization can be significant in constructed wetland systems at high ammonium concentrations in the wastewater, even at neutral $\mathrm{pH}$ (Hunt and Poach, 2001). Hence, in the present study ammonia volatilization might have contributed significantly to the removal, because of the high $\mathrm{NH}_{4}-\mathrm{N}$ concentrations, $\mathrm{pH}$ 7.9-8.9 and the high temperatures.

Plant uptake did contribute to the $\mathrm{N}$ removal, particularly at low loading rates (up to $8 \%$ of removal), but plant uptake was quantitatively of low importance compared to other removal processes as has also been shown in many other studies (Tanner et al., 2002). The effects of plants in different types of constructed wetland systems has been a matter of controversy (Brix, 1994, 1997; Tanner, 2001), but many studies have found no or very little difference between the treatment performance of planted and unplanted controls in small scale mesocosm studies (Tanner et al., 2002). In the present study, we did, however, find statistically significant effects of plants on removal of all parameters. Direct uptake of nutrients into the plant tissues were of little quantitative importance because of the high loading rates, suggesting that the positive effects of plants on removals were mainly of indirect nature. The physical effects of the plant tissues and the plant roots in the filter bed may have improved the hydraulic performance of the coarse filter medium, particularly the cracked coconut shell layer. Also, the roots increased the active surface area available for biofilm development in the filter beds. Root release of oxygen may also have contributed, as dissolved oxygen concentrations were generally higher in the effluent from planted systems $\left(0.8-3 \mathrm{mg} \mathrm{L}^{-1}\right)$ than form unplanted systems.

This study for the first time documents that $S$. sesban can be used in constructed wetland systems to treat high-strength wastewater in tropical areas and that the species grows well and produces a large amount of high nitrogen containing biomass that can be used for e.g. animal fodder and soil amendment. The study also documents that constructed wetland systems with saturated flow have a very high capacity to treat wastewater in tropical areas and that planted systems perform much better than unplanted systems. Additional studies are, however, needed to assess the longer-term performance and sustainability of such systems before they can be generally applied on a large scale.

\section{Acknowledgements}

The Danish International Development Agency (Danida) funded this work through the Cantho University-Aarhus University Link in Environmental Science (CAULES) project.

\section{References}

APHA, 1998. Standard Methods for the Examination of Water and Wastewater. American Public Health Association, Washington, DC.

Brix, H., 1994. Functions of macrophytes in constructed wetlands. Water Sci. Technol. 29, 71-78

Brix, H., 1997. Do macrophytes play a role in constructed treatment wetlands? Water Sci. Technol. 35, 11-17.

Brix, H., Arias, C.A., 2005a. Danish guidelines for small-scale constructed wetland systems for onsite treatment of domestic sewage. Water Sci. Technol. 51, 1-9.

Brix, H., Arias, C.A., 2005b. The use of vertical flow constructed wetlands for onsite treatment of domestic wastewater: new Danish guidelines. Ecol. Eng. 25, 491-500.

Dan, T.H., Brix, H., 2007. The influence of temperature, light, salinity and seed pretreatment on the germination of Sesbania sesban seeds. Afr. J. Biotechnol. 6, 2231-2235.

Dan, T.H., Brix, H., 2009. Growth responses of the perennial legume Sesbania sesban to $\mathrm{NH}_{4}$ and $\mathrm{NO}_{3}$ nutrition and effects on root nodulation. Aquat. Bot. 91, $238-244$.

Evans, D.O., Macklin, B., Anderson, D.M., Brewbaker, J.L., Gutteridge, R.C., Narayan, H., Osman, A.M., Rao, D.L.N., Steinmueller, N., Thomson, L., Topark-Ngarm, A., Yamoah, C., 1990. Perennial Sesbania Production and Use: A Manual of Practical Information for Extension Agents and Development Workers. Nitrogen Fixing Tree Association, University of Hawaii, Honolulu, USA.

Hunt, P.G., Poach, M.E., 2001. State of the art for animal wastewater treatment in constructed wetlands. Water Sci. Technol. 44, 19-25.

Indieka, S.A., Odee, D.W., 2005. Nodulation and growth response of Sesbania sesban (L.) Merr. to increasing nitrogen (ammonium) supply under glasshouse conditions. Afr. J. Biotechnol. 4, 57-60.

Kadlec, R.H., Knight, R.L., 1996. Treatment Wetlands. Lewis Publishers, Boca Raton, New York, London, Tokyo.

Kadlec, R.H., Knight, R.L., Vymazal, J., Brix, H., Cooper, P., Haberl, R., 2000. Constructed Wetlands for Pollution Control. Processes, Performance, Design and Operation. Scientific and Technical Report. International Water Association.

Kadlec, R.H., Wallace, S.D., 2009. Treatment Wetlands. CRC Press, Boca Raton, FL.

Kantawanichkul, S., Kladprasert, S., Brix, H., 2009. Treatment of high-strength wastewater in tropical vertical flow constructed wetlands planted with Typha angustifolia and Cyperus involucratus. Ecol. Eng. 35, 238-247.

Kivaisi, A.K., 2001. The potential for constructed wetlands for wastewater treatment and reuse in developing countries: a review. Ecol. Eng. 16, 545-560

Knight, R.L., 1997. Wildlife habitat and public use benefits of treatment wetlands. Water Sci. Technol. 35, 35-43.

Knight, R.L., Payne, J., Borer, R.E., Clarke, J., Pries, J.H., 2000. Constructed wetlands for livestock wastewater management. Ecol. Eng. 15, 41-55.

Konnerup, D., Koottatep, T., Brix, H., 2009. Treatment of domestic wastewater in tropical, subsurface flow constructed wetlands planted with Canna and Heliconia. Ecol. Eng. 35, 248-257. 
Mitsch, W.J., Gosselink, J.G., 2007. Wetlands. John Wiley \& Sons Inc., Hoboken, New Jersey.

Myers, R.J.K., Palm, C.A., Cuevas, E., Gunatilleke, I.U.N., Brossard, M., 1994. The synchronization of nutrient mineralization and plant nutrient demand In: Woomer P.L., Swift, M.J. (Eds.), The Biological Management of Tropical Soil Fertility. John Wiley \& Sons, Chichester, UK, pp. 81-116.

Nhan, D.K., Milstein, A., Verdegem, M.C.J., Verreth, J.A.V., 2006. Food inputs, water quality and nutrient accumulation in integrated pond systems: a multivariate approach. Aquaculture 261, 160-173.

Nhan, D.K., Verdegem, M.C.J., Milstein, A., Verreth, J.A.V., 2008. Water and nutrient budgets of ponds in integrated agriculture-aquaculture systems in the Mekong Delta, Vietnam. Aquac. Res. 39, 1216-1228.
Oovel, M., Tooming, A., Mauring, T., Mander, U., 2007. Schoolhouse wastewate purification in a LWA-filled hybrid constructed wetland in Estonia. Ecol. Eng. $29,17-26$.

Tanner, C.C., 2001. Plants as ecosystem engineers in subsurface-flow treatment wetlands. Water Sci. Technol. 44, 9-17.

Tanner, C.C., Kadlec, R.H., Gibbs, M.M., Sukias, J.P.S., Nguyen, M.L., 2002. Nitrogen processing gradients in subsurface-flow treatment wetlands-influence of wastewater characteristics. Ecol. Eng. 18, 499-520.

Vymazal, J., Greenway, M., Tonderski, K., Brix, H., Mander, U., 2006. Constructed wetlands for wastewater treatment. Wetlands Nat. Resour. Manage. 190, 69-96. Young, A., 1997. Agroforestry for Soil Management. CAB International, Wallingford UK. 